Max-Planck-Institut für demografische Forschung

Max Planck Institute for Demographic Research

Konrad-Zuse-Strasse 1 - D-18057 Rostock · GERMANY

Tel +49 (0) 3812081 - 0; Fax +49 (0) 3812081 - 202;

http://www.demogr.mpg.de

MPIDR WORKING PAPER WP 2006-005

MARCH 2006 (REVISED DECEMBER 2006)

\title{
Fertility Developments in Morocco: Progression to Third Birth
}

Agata V. D'Addato (daddato@ demogr.mpg.de)

This working paper has been approved for release by: Jan M. Hoem (hoem@demogr.mpg.de)

Head of the Laboratory of Contemporary European Fertility and Family Dynamics.

(C) Copyright is held by the authors.

Working papers of the Max Planck Institute for Demographic Research receive only limited review. Views or opinions expressed in working papers are attributable to the authors and do not necessarily reflect those of the Institute. 


\title{
Fertility Developments in Morocco: Progression to Third Birth
}

\author{
Agata V. D'Addato \\ Institut National d'Études Démographiques fellow, Paris \\ European Doctoral School of Demography at the Max Planck Institute for Demographic Research, Rostock \\ daddato@demogr.mpg.de
}

\begin{abstract}
:
Nowadays, throughout Morocco a dynamic process of modernization is embracing fertility and nuptial behaviors, family planning, contraceptive use, the role and status of women in the family as well as in society, and political orientations, challenging the foundations of the patriarchal system. The progression from second to third birth is a crucial step in fertility change during fertility transition since the reduction especially in third and higher-order births maintains fertility decline. For these reasons, the study aims at analyzing the main determinants of third-birth intensities, applying an eventhistory analysis to the most recent retrospective Moroccan survey data. The findings show that differences among social groups still persist: higher risks of giving birth to the third child characterize women with a lower educational level and experiencing a rural background. Nevertheless, within the framework of the ongoing process of modernization in the country and geared to promote women's status, all segments of the population are rapidly changing their fertility behaviors. Third-birth fertility appears to decline monotonically for all educational groups. This suggests that the general drop in Morocco is due to general period effects that affect all strata of the population and various composition effects where increasingly large groups join the socio-economic groups that have the lowest fertility. Moreover, the analysis shows no consistent or clear evidence of sex preference among Moroccan mothers in the progression to the third child. There seems to be a slight aversion towards having two girls; however, this tendency admittedly is not statistically significant.
\end{abstract}




\section{Introduction}

The fertility patterns of the South and East Mediterranean shores are very different from those of the lowest-low fertility countries of the Northern shore, but recently fertility decline has been spreading rapidly in the former region, especially in Maghreb (Di Comite and Moretti 1999; Héran 2004).

My analysis focuses on Morocco, which is nowadays characterized by a decline of fertility levels and by important changes in the intermediate determinants. In general, if the first phase of fertility transition is marked by an increase in the age at marriage, in the long term a diffusion tendency towards the nuclear family plays an even greater role for countries in an advanced transitional phase, such as Morocco. Therefore, the progression from second to third birth is a crucial component in fertility change, since the reduction especially of third and higher-order births maintains the fertility decline (Yavuz 2005).

For these reasons, the study aims at analyzing the main determinants of the third-birth intensities of two-child mothers, applying an event-history analysis to the most recent Moroccan retrospective survey data.

Section 2 provides some key aspects of fertility transition in Morocco and states the research hypotheses. Section 3 specifies the data and methods used, and describes some preliminary descriptive findings. In Section 4, the results are discussed, and the final section summarizes and concludes the analysis.

\section{Theoretical background and research hypotheses}

Morocco of today is experiencing a dynamic process of modernization, affecting fertility and nuptial behaviors, family planning, contraceptive use, the role and status of women in the family as well as in society, political orientations, and posing a challenge to the very foundations of the patriarchal system (Salvini 1994, Fargues 1995, 2003).

Until the Sixties, Morocco has kept a typically pre-transitional demographic regime, characterized by very high fertility and mortality levels. In the following decades, the social, economic, and political evolution of the country as well as the consequent impact on people's mentalities and attitudes towards procreation have determined deep demographic changes at each level. In particular, Morocco was close to natural fertility in the Sixties, with 6.96 children per woman (CERED 1997). The period fertility rate rose in the early Seventies, peaking at 7.40 only to continue an unbroken decline since the mid-1970s (Figure 1).

Especially the Eighties represented the final trigger that was associated with a change in Moroccan reproductive behavior under the effect of radical socio-economic changes in the country, such as rising women's educational attainment and participation in the labor market, knowledge about and access to contraceptives and strong urbanization. All these factors, together with economic recession (falling phosphate prices) ${ }^{1}$ and a political/military crisis (tensions in the Sahara) led to a sharp decline in

\footnotetext{
1 After a temporary sharp increase in phosphate prices in the early 1970s, leading to a boom in expenditure, the Moroccan economy ran into major problems in the mid-1970s, as the global recession set in phosphate prices collapsed. Export and revenue decline forced the government to raise personal income taxes as well as scale back subsidies for health care, education, food subsidies, and housing. The new role
} 
Moroccan fertility, falling to 5.52 in 1982, 4.46 in 1988, 3.28 in 1994, 2.80 in 1999, and more recently, 2.50 according to the Demographic and Health Survey of 2003/04 (for the three years preceding the survey). In terms of fertility transition, there is no uniformity across the country in the change because different sections of the population have been affected by social and cultural changes in different ways and at varying pace. The trends in urban and rural fertility indicate that some parts of the population are already rapidly pointing to below-replacement fertility: according to the last DHS, the TFR was 2.10 in urban areas and 3.00 in rural settings (Figure 1).

Figure 1: Total fertility rate by place of residence in Morocco, 1973-2003.

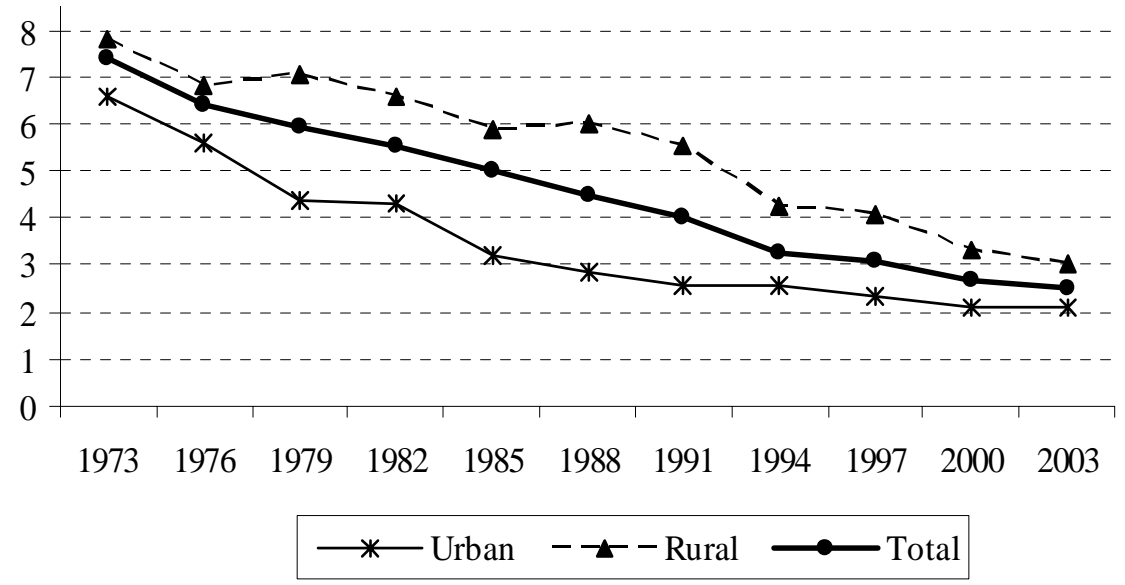

Source: own calculations based on Moroccan Statistical Office data, various years.

As it is well documented in the literature, the gradual decline of fertility levels in Morocco depends on the joint action of several factors. Especially increasing educational standards are traditionally considered an essential determinant of the changes in women's reproductive choices. It is generally argued that female education represents the keystone to the transition from traditional fertility regime to modern ones (Fargues 1988, 1995). Until the mid-1970s, the commonly held view was that fertility fell uniformly with education. This view was consonant with the classic model of demographic transition, which hypothesizes steady fertility decline concurrent with a process of socioeconomic development. Education then seems to remove the divergences in fertility among different countries; such differences continue to be high only for illiterate women, they are still perceptible for women with a low to medium level of education, and are negligible for the better educated ones (Fargues 1988). However, an extensive review of the available empirical evidence up to the late 1970s casts doubts on these long-held assumptions (Cochrane 1979). The expected inverse association was not found in many poor, mostly illiterate, rural societies. Instead, an inverted U-shaped relationship was documented in several developing countries. As it has clearly been underlined by Courbage (1994a, 1994b, 1994c, 1999), the relationship

of government was not as a giver but as a taker of incomes, and it drove a renewed imperative: family self-reliance (Courbage 1995, Deane Abernethy 2002). 
between education and fertility appears extremely changeable depending on the countries and, especially in the Mediterranean macro region, it sometimes reveals deep ambiguities, in particular in the Arabic countries, such as Syria, Egypt, and Kuwait. In general, it can be argued that the impact of individual schooling on reproductive behavior varies over countries depending on the stage they are at in the fertility transition: the effect is weak in mostly illiterate societies, it grows stronger as societies improve their overall education and advance in their transitional phase - such as Morocco -, and it becomes less prominent again in societies that have just passed the fertility transition, and once a relatively low level of fertility has been reached. In Morocco, girls who reach a secondary level of schooling are more likely to delay marriage and childbearing, their children tend to be healthier and their participation in the labor force is relatively higher (CERED 1997, 1998).

Education affects the quantum and tempo of fertility partly through its impact on age at marriage (Smith 1983). Because in most developing countries in general, and in Morocco in particular, childbearing takes place within the context of conjugal union, and nuptiality patterns are closely linked to fertility patterns, marriage and childbearing are viewed as interrelated social and demographic events, and as sequential phases in the life cycle of women. Thus, a higher female age at marriage and later family formation thereby are factors that have significantly contributed to depress fertility in Morocco. In fact, higher age at marriage reduces the average interval of procreation because of the contraction of the exposure period to childbearing. In particular, the average age of women at first marriage, which was 18.8 according to the Moroccan Demographic and Health Survey of 1992, rose to 21.4 according to the last Demographic and Health Survey of 2003/04 (Azelmat, Ayad, and Abdelmoneim 2005). The rarefaction of some very common familial models, such as polygamy and repudiation, which encouraged high fertility in the past, can also be considered a pivotal aspect in the decline of Moroccan fertility, as well as the progress achieved in maternal and infant mortality, because the perceived increase of survival should lead to lower fertility.

In addition, reproductive behavior is changing as the result of strong urbanization in the country, a process from which arouses the preference towards smaller families. Urbanization implies, from a demographic point of view, the concentration of the population in urban areas, and from a sociological point of view, the diffusion of "urban behaviors": individualism, isolation, anonymity, and competition; features which lead to families less extended and to a weaker patriarchal system.

The effect of governmental actions aimed at decreasing the fertility level has significantly contributed to the diffusion of contraceptive methods and to the improvement in the female status, having a strong effect on fertility transition. It is generally argued that family planning programs are successful only if they jointly act with important socio-economic changes, promoting women's status and arousing the desire to limit the family size (Mason 1985). All these factors have contributed to push women's emancipation from their traditional role of being wives and mothers to enhance women's position within the family authority structure, and to promote the development of the decisional autonomy, playing a major role in shaping fertility behavior.

In the inception and the rapid crossing of the transitional process, and in the diffusion of low fertility, the indirect effect of international migration on the mentality 
of non-migrants as well as on the whole society of origin may also have played an important role. Openness to the outside world, and notably to extranational living models and customs through international migration, may contribute to differences in fertility rates, thanks to relationships with emigrants and the mass media. As Courbage puts it, "La migration internationale, ses apports en capitaux, génère une intensification agricole qui incite au calcul économique plus sophistiqué et à des stratégies familiales adaptées: moins d'enfants mais mieux formés, par exemple. De surcroît, par un effet de mimétisme, la migration internationale a des effets en boule de neige. Les familles de non-migrants, doivent, pour ne pas perdre leur statut social, trouver des alternatives viables et évoluer" (2001, page 474).

Therefore, the reproductive choices are clearly a reflex action both of cultural and socioeconomic factors. Substantial developmental changes have occurred over the last decades in Morocco owing to many factors that are generally believed to be conducive to fertility decline.

However, even though unequivocal signs confirm that a multidimensional process of modernization is taking place in Morocco, this process seems to be diversified in terms of speed and determined by the stratifications still persisting in the population, specifically in terms of economic well-being, education, residence, and the gender system (Barsotti and Lecchini 2003; Paterno, Gabrielli, and D'Addato 2006).

Thus, I would like to see through an analysis of current individual data whether or not there are "pioneer" subgroups with low fertility, e.g. higher educated women or women who have been brought up within an urban context.

On the basis of the literature, I expect that the status of women impacts reproductive behavior, causing differentiated risks for third birth. I am specifically interested in verifying the hypotheses that postponement of marriage, spacing of births, increased educational standards, and an urban background lead to a higher propensity to establish smaller families. In addition, according to previous studies couples in many countries express a decided preference for children of a particular sex and their preference is attributable to a variety of social, economic, and cultural factors (Makhlouf Obermeyer 1996, 1999; Clark 2000; Dalla Zuanna and Leone 2001). A strong preference for children of a particular sex may be a significant obstacle to fertility decline if couples who have already reached their desired family size continued childbearing to try for a child of the preferred sex (Da Vanzo and Starbird 1991). Preference towards a son is prevalent in many regions of the world, but the preference for a balanced number of daughters and sons is also common; even where the son preference is strong, couples usually express a desire to have at least one child of each sex (Makhlouf Obermeyer and Cardenas 1997). For example, analyzing Demographic and Health Surveys from 26 countries, Arnold (1992) reports that the most common pattern of sex-preference is for at least one son and one daughter. Contraceptive use in a number of countries also shows preference for a balanced number of sons and daughters, often along with a moderate son preference (for example, in Kenya, Morocco and Tunisia). When related to fertility transition, one may want to argue that the evidence of possible sex preferences should be strengthened as family size decreases and third-birth progression increasingly becomes a deliberate choice. Thus, gender composition may play a large role within a low-fertility setting, such as contemporary Morocco ${ }^{2}$.

\footnotetext{
${ }^{2}$ Yet, the preference towards a son may also be related to subcultures existing in the country: Morocco has predominantly Berber regions; it is not a homogeneously Arab nation. If the parental gender
} 


\section{Data, preliminary findings, and methods}

The analysis is carried out using data from the most recent retrospective survey, l'Enquête sur la Population et la Santé Familiale (EPSF) 2003/04, conducted in Morocco as part of the Demographic and Health Surveys (Azelmat, Ayad, and Abdelmoneim 2005). It was designed to provide information on the fertility levels and trends, infant and child mortality, family planning, and mother and child health of a nationally representative sample of the Moroccan population. The survey was fielded between October 2003 and February 2004. Face-to-face interviews were carried out in 11513 households and involved 16798 women: all women aged 15 to 49 who were present in the household in the night before the interview or who generally lived in the household were eligible to take part in the survey. A weighted, multi-stage, stratified cluster sampling approach was used in the selection of the sample.

A first glance at the progression to third birth in Morocco shows significant differentials in behavior according to some socio-demographic characteristics of women and their husbands, such as the educational level ${ }^{3}$, the childhood place of residence, and the sex composition of children born previously (Table 1).

Constant higher proportions of literate women, married to highly educated men and having lived in urban settings, who have not experienced third birth 5 and 10 years after second child birth, suggest that the more emancipated strata of the population postpones higher order births. Thus, the preliminary outcomes highlight the complexity of the picture, revealing marked differences in the transition to third birth among the population subgroups. By contrast, rather balanced percentages of mothers who have never experienced third child birth 5 and 10 years into the second birth, by the sex composition of the previous children, may suggest an attenuated effect of this variable on reproductive behaviour.

Basic socio-economic and demographic characteristics of women - related to the cultural context of fertility behavior - are investigated, using a piecewise constant intensity regression model on the probability of having a third birth. Because marriage is almost universal in Morocco and practically all births occur within marital unions, my analysis focuses on a sub-sample consisting of 5,645 currently married women (married only once) aged 15 to 49 who have already given birth to the second child at the time of interview (excluding cases with twins at second birth), and who were at risk of birth (starting 8 months after second child birth) ${ }^{4}$. Particularly, a woman's third-birth risk is defined as the probability that she will experience third birth the next month, given her individual and couple characteristics and given that she has not had such birth by the beginning of the month. Risks are assumed to be constant within each time interval but may vary across such intervals. In my analysis, the process time (i.e. the baseline hazard) is the number of months elapsed since the birth of the second child. Next, I include a time-varying covariate aiming to capture the influence of changes in the socio-

preferences are stronger among Arab populations than they are among the Berber population, as it has been suggested, then the ethnic and linguistic diversity of the country may weaken the degree of the son preference (Makhlouf Obermeyer and Cardenas 1997). A thorough examination of the differences between the Arab and Berber nation, however, would require a careful mapping of the settlement patterns of the two groups. The data, however, are not well suited to this purpose and such analysis is beyond the scope of the present study.

${ }^{3}$ The inclusion of the highest level of education ever reached is justified by the assumption that women and men have already concluded their education career at the time of second birth.

${ }^{4}$ The exposures have a median age of 27.1 years. 
political environment on third-birth intensity. I use three time periods in this categorization: until 1993, from 1994 to 1998, and from 1999 to the date of interview. My choice is motivated by the following reasons: (a) in 1993, the first royal reform of the Personal Status Code (Mudawwana, officially issued in 1957) was introduced, (b) in 1998, the "Plan national pour l'intégration de la femme au développement" was launched, and (c) in 1999, Muhammad VI, a liberal sovereign, was enthroned, with the declared intention to pursue democratic reform, improve women's conditions and assure human dignity ${ }^{5}$. These broad legal reforms are expected to have given women more choice in matters of reproduction and contributed to compress the family size. In fact, the strategies that are used by the state to consolidate its power have profound implications on the female status. In the countries of the Maghreb, for instance, the status of women reflects the different processes of state formation, and is, to a large extent, a function of the relationship between the state and existing kinship structures (Charrad 1990).

Even though the Moroccan Demographic and Health Survey includes a wide range of retrospective questions on birth histories and contraceptive use of women, most background characteristics were not collected with individual life histories (e.g. information on migration, employment, and the family cycle were obtained only at the time of the survey). It was almost impossible, then, to examine these variables in conjunction with preceding births and to regard them as explanatory variables due to the risks of performing an anticipatory analysis (Hoem 1996).

The sub-sample used in this analysis indicates that around $70 \%$ of the women and half of their husbands have no formal education. This is consistent with Moroccan schooling levels. With regard to the urban-rural distribution of the Moroccan mothers included in the analysis, about $66 \%$ lived in rural areas during their childhood, reflecting the low levels of urbanization in the country in the past. Half of the two-child women got married early, i.e. by the time they reached 19 years of age, and for nearly $64 \%$ of them the time interval between the first two births was not shorter than two years.

\footnotetext{
${ }^{5}$ The official issue of the new Family Code on $9^{\text {th }}$ February 2004 is characterized by the direct involvement of Muhammad VI.
} 
Table 1: Transition from second to third birth, by selected socio-demographic characteristics in Morocco. Kaplan-Meier survival curve estimates.

\begin{tabular}{|c|c|c|c|c|}
\hline $\begin{array}{c}\text { Socio-demographic } \\
\text { variables }\end{array}$ & $\begin{array}{c}\text { Women never } \\
\text { having } \\
\text { experienced } \\
\text { 3rd child birth, } \\
5 \text { years since } \\
\text { the } 2^{\text {nd }} \text { birth } \\
(\%) \\
\end{array}$ & $\begin{array}{l}\text { Women never } \\
\text { having } \\
\text { experienced } \\
\text { 3rd child birth, } \\
10 \text { years since } \\
\text { the } 2^{\text {nd }} \text { birth } \\
(\%) \\
\end{array}$ & $\begin{array}{l}\text { Duration at } \\
\text { which } 25 \% \text { of } \\
\text { women } \\
\text { experience 3rd } \\
\text { child birth } \\
\text { (years) }\end{array}$ & $\begin{array}{l}\text { Duration at } \\
\text { which } 50 \% \text { of } \\
\text { women } \\
\text { experienced } \\
\text { 3rd child birth } \\
\text { (years) }\end{array}$ \\
\hline \multicolumn{5}{|l|}{$\begin{array}{l}\text { Childhood place of } \\
\text { residence }\end{array}$} \\
\hline Rural & 19.4 & 7.0 & 1.8 & 2.7 \\
\hline Urban & 43.2 & 21.5 & 2.5 & 4.4 \\
\hline \multicolumn{5}{|l|}{$\begin{array}{l}\text { Woman's educational } \\
\text { level }\end{array}$} \\
\hline No education & 16.2 & 6.1 & 1.8 & 2.5 \\
\hline Primary & 35.3 & 12.9 & 2.2 & 3.8 \\
\hline Secondary and higher & 53.4 & 26.8 & 3.0 & 5.3 \\
\hline \multicolumn{5}{|l|}{$\begin{array}{l}\text { Partner's educational } \\
\text { level }\end{array}$} \\
\hline No education & 15.7 & 5.8 & 1.7 & 2.5 \\
\hline Primary & 25.3 & 9.2 & 2.0 & 3.1 \\
\hline Secondary and higher & 44.0 & 21.5 & 2.0 & 4.4 \\
\hline \multicolumn{5}{|l|}{$\begin{array}{l}\text { Sex composition of } \\
\text { children born } \\
\text { previously }\end{array}$} \\
\hline Two girls & 23.4 & 8.7 & 1.9 & 2.9 \\
\hline One boy and a girl & 24.1 & 10.1 & 1.9 & 2.9 \\
\hline Two boys & 23.8 & 9.9 & 1.9 & 2.8 \\
\hline
\end{tabular}

Source: own calculations based on DHS 2003/04, Morocco.

\section{Results}

The model parameters, produced as maximum-likelihood estimates, are presented in the form of relative risks (Table 2). As expected, later marriage is associated with lower third-birth intensity, although the decrease seems to be quite marginal. The model has also been controlled for the length of the previous birth interval: short intervals between the first and the second child are associated with higher transition rates, while long intervals are associated with lower ones.

The childhood place of residence and the educational composition of the population are two important predictors of fertility change: those who spent their childhood in a rural context and those who have a lower level of education are characterized by a higher transition rate from the second child to the third. In Morocco, female education in particular appears to be a determinant aspect in the course of fertility, regardless of the socio-economic. Greater female access to education and greater educational opportunities (although these are wider in urban areas) are significant, and schools are also important agents of socialization, playing a crucial role 
in shaping attitudes, opinions, and values. Not only women but also husbands' higher educational standards significantly impact the propensity of giving birth to the third child. The results in the model show that the risk of having the third child decreases at a similar intensity both for better educated women and men - with primary schooling as well as with secondary education - compared to the least educated subgroups. The Ushaped relationship between education and fertility documented in several developing countries is not found; instead, it seems that fertility falls uniformly as the educational attainment of women and husbands rises ${ }^{6}$. A model including an interaction term between female and male educational levels was finally fitted; the outcomes, however, showed no strong and meaningful effects among the categories considered (Table A1 in the Appendix).

As for the calendar period, the first period has the highest progression risk and then the risk diminishes at each subsequent level. In the last period, the risk is $46 \%$ lower than for the period until 1993. Finally, there seems to be a slight tendency towards a boy preference in the progression from second to third birth, even if this tendency admittedly is not statistically significant. The introduction of the interaction between the calendar period and the sex composition of the previous offspring did not produce significant results: it rather showed that there is no real interaction at all. The results also reveal that none of the differences within calendar periods is significant (Table A2 in the Appendix).

In order to catch the process of fertility declining over time by women's educational level, an interaction model was fitted but the results reveal that all segments of population are rapidly changing their fertility behavior; third-birth appears to decline monotonically across all educational groups at a similar rate (Table A3 in the Appendix). Within the framework of ongoing modernization, even the most "laggard" group - such as illiterate women - shows a decrease in third-birth intensity during the 1990s. The lack of strong interaction between women's educational attainment and time period challenges some of the assumptions on how fertility changes when transition advances.

The author also did not find significant interaction between woman's educational level and the sex composition of children previously born: none of the differences among the categories were substantially meaningful (Table A4 in the Appendix).

\footnotetext{
${ }^{6}$ Note that men's educational level is a variable reflecting their wives perception, with information not directly requested of their husbands.
} 
Table 2: Relative risk (and level of significance) of giving third child birth for two-child mothers, standardized by selected socio-demographic characteristics, Morocco, 2003/04.

\begin{tabular}{|c|c|c|}
\hline Variables & Relative Risks & p-values \\
\hline \multicolumn{3}{|l|}{ Age at first marriage } \\
\hline$<20$ & 1.00 & \\
\hline $20-22$ & 0.96 & 0.332 \\
\hline $23-25$ & 0.88 & 0.013 \\
\hline$>25$ & 0.72 & 0.000 \\
\hline \multicolumn{3}{|c|}{ Length of previous birth interval } \\
\hline$<2$ years & 1.00 & \\
\hline 2 years or more & 0.54 & 0.000 \\
\hline \multicolumn{3}{|l|}{ Calendar period } \\
\hline $1989-1993$ & 1.00 & \\
\hline 1994-1998 & 0.69 & 0.000 \\
\hline $1999-2003 / 04$ & 0.54 & 0.000 \\
\hline \multicolumn{3}{|l|}{ Childhood place of residence } \\
\hline Rural & 1.00 & \\
\hline Urban & 0.77 & 0.000 \\
\hline \multicolumn{3}{|l|}{ Woman's educational level } \\
\hline No education & 1.00 & \\
\hline Primary & 0.85 & 0.002 \\
\hline Secondary and higher & 0.73 & 0.000 \\
\hline \multicolumn{3}{|l|}{ Husband's educational level } \\
\hline No education & 1.00 & \\
\hline Primary & 0.85 & 0.000 \\
\hline Secondary and higher & 0.75 & 0.000 \\
\hline \multicolumn{3}{|c|}{ Sex composition of previous children } \\
\hline Two girls & 1.00 & \\
\hline One boy and a girl & 0.95 & 0.203 \\
\hline Two boys & 0.93 & 0.067 \\
\hline \multicolumn{3}{|l|}{ Duration since second birth ${ }^{\text {a) }}$} \\
\hline$<1.50$ year & 1.00 & \\
\hline $1.50-2.49$ years & 4.15 & 0.000 \\
\hline $2.50-3.99$ years & 4.84 & 0.000 \\
\hline 4.00-5.99 years & 4.93 & 0.000 \\
\hline $6.00-18.50$ years & 3.09 & 0.000 \\
\hline
\end{tabular}

Source: own calculations based on DHS 2003/04, Morocco.

a) The duration has been computed starting from 8 months following second child birth.

\section{Conclusions}

The process of fertility transition is now ongoing in all of the South and East Mediterranean countries, so that the present fertility level is about half of that of the Seventies. Widely available education and urbanization have influenced reproductive behavior and, despite the limited presence of females in the labor market, the irreversible drop in fertility is leading to considerable social transformations, such as the erosion of the patriarchal system and the promotion of women's empowerment. 
This analysis has focused on Morocco, a country that experiences dynamic and multidimensional modernization characterized by the diffusion of the less extended family. The progression from second to third birth has been analyzed because it represents a pivotal step of family building during advanced fertility transition.

The findings point out that differences among social groups still persist in Morocco: women with a lower educational level and with a rural background display higher risks of third child birth. Nevertheless, the analysis has also demonstrated that the dynamic process of modernization under way in the country, addressed at the promotion of women's empowerment, acts also on the fertility behavior of women who still have a low educational level. Third-birth fertility appears to decline monotonically for all educational groups. This suggests that the general drop in Morocco is due to general period effects that affect all strata of the Moroccan population and various composition effects where increasingly large groups join the socio-economic groups that have the lowest fertility. Therefore, if the ongoing trend towards higher female educational standards and towards the promotion of their social status continues in Morocco, we can expect a smaller number of large families in the close future. Women's position and emancipation are key concerns in implementing further declines in the propensity to establish smaller families. A national challenge will be to narrow, and eventually eliminate, the persistent wide gaps among the subgroups of the population.

Moreover, the analysis shows no consistent or clear evidence of sex preference among Moroccan mothers in the progression to the third child. There seems to be a slight aversion towards having two girls, which makes sense as gender composition may be strengthened factor in a low-fertility setting; however, this tendency admittedly is not statistically significant.

\section{Acknowledgements}

This project was carried out during my stay at the Max Planck Institute for Demographic Research as a fellow in the European Doctoral School of Demography. I am grateful to Jan Hoem for his useful teaching during the Winter-Semester 2005/06. Paola Di Giulio is gratefully acknowledged for the insightful comments on an earlier version of the manuscript. I would also like to thank Daniele Vignoli for the motivating exchange of opinions during elaborations on the analysis, and Susann Backer for the valuable language editing of this paper. 


\section{References}

ARNOLD F. (1992). "Sex Preference and Its Demographic and Health Implications". International Family Planning Perspectives, 18, 3: 93-101.

Azelmat M., Ayad M., Abdelmoneim A. (2005). Enquête sur la Population et la Santé Familiale (EPSF) 2003/04. Ministère de la Santé Publique (Maroc), Macro International Inc, Ligue des États Arabes.

BARSOTTI O., LECCHINI L. (a cura) (2003). Transizioni e contraddizioni. Demografia e sviluppo in Marocco secondo un'analisi di genere. Pisa: Edizioni Plus.

CERED (1997). Situation et perspectives démographiques du Maroc. Rabat: Royaume du Maroc, Premier Ministre, Ministère de la Prévision Économique et du Plan.

CERED (1998). Population et développement au Maroc. Rabat: Royaume du Maroc, Premier Ministre, Ministère de la Prevision Économique et du Plan.

Charrad M. (1990). State and gender in the Maghreb, Middle East Report MarchApril: 19-24.

Clark S. (2000). "Son preference and sex composition of children: Evidence from India". Demography, 37, 1: 95-108.

Cochrane S. (1979). Fertility and Education: What Do We Really Know?. Baltimore: Johns Hopkins University Press.

Courbage Y. (1994a). "Évolution démographique et attitudes politiques en Syrie". Population, 3: 725-749.

Courbage Y. (1994b). "L’imprévisible fécondité égyptienne”. Population, 1: 211-222.

Courbage Y. (1994c). Péninsule arabique: les surprises de la démographie, MaghrebMachrek, 144.

Courbage Y. (1995). Fertility transition in the Mashriq and Maghrib, in Makhlouf Obermeyer C. (ed.), "Family, gender and population in the Middle East". Cairo: The American University in Cairo Press: 80-104.

Courbage Y. (1999). Nouveaux horizons démographiques en Méditerranée, Travaux et Documents, 142. Paris: INED (updated English version: http://www.ined.fr/englishversion/publications/collections/courbage/td142A.htm).

Courbage Y. (2001). Sur les pas de l'Europe du Sud: la fécondité au Maghreb (http://www.un.org/esa/population/publications/completingfertility/RevisedCourbagepa per.PDF). 
Dalla Zuanna G., Leone T. (2001). "A Gender Preference Measure: the Sex Ration at Last Birth". Genus, 57, 1: 33-56.

DAVANZO J., STARBIRD H. (1991). "Correlates of short inter-birth intervals in peninsular Malaysia: Their pathway of influence through breastfeeding and contraceptive use". Studies in Family Planning, 22, 4: 241-254.

DeAne Abernethy V. (2002). Fertility decline; no mistery, Ethics in Science and Environmental Politics (http://www.int-res.com/articles/esep/2002/article1.pdf).

Di Comite L., Moretti E. (1999). Geopolitica del Mediterraneo. Roma: Carocci.

FArgues Ph. (1988). "Baisse de la fécondité arabe”. Population, 43, 6: 975-1004.

FARGUES Ph. (1995). Changing hierarchies of gender and generation in the Arab World, in Makhlouf Obermeyer C. (ed.), "Family, gender and population in the Middle East", Cairo: The American University in Cairo Press: 80-104.

FARGUES Ph. (2003). "La femme dans les pays arabes: vers une remise en cause du système patriarcal”. Population et Sociétés, 387.

HerAn F. (2004). “Cinq idées reçues sur l'immigration”. Population et Sociétés, 397.

HoEM J.M. (1996). "The harmfulness or harmlessness of using an anticipatory regressor: how dangerous is it to use education achieved as of 1990 in the analysis of divorce risks in earlier years?". Yearbook of Population Research in Finland, 33.

MAKHLOUF OBERMEYER C. (1996). "Fertility norms and son preference in Morocco and Tunisia: does women's status matter?'. Journal of Biosocial Science, 28: 57-72.

MAKHLOUF OBERMEYER C. (1999). Fairness and fertility: The meaning of son preference in Morocco, in Leete R. (ed.), "Dynamics of Values in Fertility Change". London: Oxford University Press: 275-292.

Makhlouf Obermeyer C., Cardenas R. (1997). "Son preference and Differential Treatment in Morocco and Tunisia". Studies in Family Planning, 28, 3: 235-244.

MASON K. (1985). The Status of Women. New York: The Rockfeller Foundation.

PAterno A., Gabrielli G., D'AdDAto A.V. (2006). Travail des femmes, caractéristiques familiales et sociales: le cas du Maroc, paper presented at the AIDELF Conference, 18-22 September 2006, Aveiro.

SALVINI S. (1994). Trasformazioni economiche, pressioni demografiche e cambiamenti della società patriarcale negli stati che si affacciano sull'altra sponda del Mediterraneo. Politica internazionale, 2. 
SMITH P. (1983). The impact of age at marriage and proportions marrying on fertility, in Bulutao R. and Lee R., "Determinants of Fertility in Developing Countries". New York Academic Press, 2: 473-531.

YAVUZ S. (2005). Fertility transition and progression to third birth in Turkey. MPIDR Working Papers, WP-2005-028. 


\section{Appendix}

Table A1: Relative risk (and level of significance) of giving third childbirth for twochild mothers, by interaction between woman's and husband's educational level, standardized by selected socio-demographic characteristics, Morocco, 2003/04.

\begin{tabular}{lccc}
\hline & \multicolumn{3}{c}{ Woman's educational level } \\
\cline { 2 - 4 } & No education & Primary level & $\begin{array}{c}\text { Secondary and } \\
\text { higher }\end{array}$ \\
\hline Husband's educational level & & & \\
No education & 1.00 & $0.85(0.000)$ & $0.74(0.000)$ \\
Primary & $0.72(0.000)$ & $0.67(0.000)$ & $0.67(0.000)$ \\
Secondary and higher & $0.72(0.022)$ & $0.57(0.000)$ & $0.44(0.000)$ \\
\hline
\end{tabular}

Source: own calculations based on DHS 2003/04, Morocco. The interaction is controlled for all the other factors considered in the model presented in Table 2.

Table A2: Relative risk (and level of significance) of giving third child birth for twochild mothers, by interaction between calendar period and sex composition of previous children, standardized by selected socio-demographic characteristics, Morocco, 2003/04.

\begin{tabular}{lccc}
\hline & \multicolumn{3}{c}{ Calendar period } \\
\cline { 2 - 4 } & $1989-1993$ & $1994-1998$ & $1999-2003 / 04$ \\
\hline Sex composition of & & & \\
previous children & 1.00 & 1.00 & 1.00 \\
Two girls & $0.99(0.781)$ & $0.93(0.402)$ & $0.95(0.538)$ \\
One boy and a girl & $0.96(0.468)$ & $0.89(0.267)$ & $0.88(0.151)$ \\
Two boys &
\end{tabular}

Source: own calculations based on DHS 2003/04, Morocco. The interaction is controlled for all the other factors considered in the model presented in Table 2.

Table A3: Relative risk (and level of significance) of giving third childbirth for twochild mothers, by interaction between calendar period and woman's educational level, standardized by selected socio-demographic characteristics, Morocco, 2003/04.

\begin{tabular}{lccc}
\hline & \multicolumn{3}{c}{ Calendar period } \\
\cline { 2 - 4 } & $1989-1993$ & $1994-1998$ & $1999-2003 / 04$ \\
\hline Woman's educational level & & & \\
No education & 1.00 & $0.66(0.000)$ & $0.51(0.000)$ \\
Primary & $0.79(0.002)$ & $0.60(0.000)$ & $0.47(0.000)$ \\
Secondary and higher & $0.58(0.000)$ & $0.54(0.000)$ & $0.42(0.000)$ \\
\hline
\end{tabular}

Source: own calculations based on DHS 2003/04, Morocco. The interaction is controlled for all the other factors considered in the model presented in Table 2. 
Table A4: Relative risk (and level of significance) of giving third childbirth for twochild mothers, by interaction between woman's educational level and the sex composition of previous children, standardized by selected socio-demographic characteristics, Morocco, 2003/04.

\begin{tabular}{lccc}
\hline & \multicolumn{3}{c}{ Woman's educational level } \\
\cline { 2 - 4 } & No education & Primary level & $\begin{array}{c}\text { Secondary } \\
\text { and higher level }\end{array}$ \\
\hline $\begin{array}{l}\text { Sex composition of } \\
\text { previous children }\end{array}$ & & & \\
Two girls & 1.00 & $0.93(0.406)$ & $0.62(0.000)$ \\
$\begin{array}{l}\text { One boy and a girl } \\
\text { Two boys }\end{array}$ & $0.98(0.739)$ & $0.75(0.000)$ & $0.61(0.000)$ \\
\hline
\end{tabular}

Source: own calculations based on DHS 2003/04, Morocco. The interaction is controlled for all the other factors considered in the model presented in Table 2. 